University of Rhode Island

DigitalCommons@URI

The Rhode Island Current Conditions Index

Economics

$11-2006$

\title{
Rhode Island Current Conditions Index - November 2006
}

Leonard Lardaro

University of Rhode Island, lardaro@uri.edu

Follow this and additional works at: https://digitalcommons.uri.edu/ricci

Part of the Econometrics Commons

Terms of Use

All rights reserved under copyright.

\section{Recommended Citation}

Lardaro, Leonard, "Rhode Island Current Conditions Index -- November 2006" (2006). The Rhode Island Current Conditions Index. Paper 72.

https://digitalcommons.uri.edu/ricci/72

This Article is brought to you for free and open access by the Economics at DigitalCommons@URI. It has been accepted for inclusion in The Rhode Island Current Conditions Index by an authorized administrator of DigitalCommons@URI.For more information, please contact digitalcommons-group@uri.edu. 
Rhode Island's economic performance in November was more in line with what it has been "on average" throughout this year. After posting a stellar Current Conditions Index value of 83 in October, November saw a decline back to 58, as only seven of twelve indicators improved. The one thing that is evident from November's performance is we have returned to a period where strength offsets weakness. The strength this month, however, was generally less than I was hoping for.

Long-overdue improvement in two indicators continued in November. Single-Unit Permits, which reflect new home construction, increased by 16.5 percent compared to last November, its second consecutive double-digit increase. And US Consumer Sentiment rose by 13.1 percent, its third consecutive monthly rise, aided by declining gasoline and energy prices in November. Ironically, even though sentiment improved, Retail Sales fell by 1.3 percent in November, its

\begin{tabular}{lc}
\multicolumn{2}{c}{ CCI I ndicators - \% Change } \\
Government Employment & -0.9 \\
US Consumer Sentiment & 13.1 Y \\
Single-Unit Permits & $16.5 \mathbf{Y}$ \\
Retail Sales & -1.3 \\
Employment Services J obs & $5.4 \mathbf{Y}$ \\
Priv. Serv-Prod Employment & $0.6 \mathbf{Y}$ \\
Total Manufacturing Hours & $0.4 \mathrm{Y}$ \\
Manufacturing Wage & $1.3 \mathbf{Y}$ \\
Labor Force & $0.7 \mathbf{Y}$ \\
Benefit Exhaustions & 4.1 \\
New Claims & 3.2 \\
Unemployment Rate & 2.0 \\
\multicolumn{1}{|c}{ Y = I mproved Value } \\
\end{tabular}

first decline in the last three months. In spite of November's decline, though, Retail Sales continues to trend upward.

The return of offsetting behavior was evident with the dual improvement in new home construction and sentiment being nullified by the simultaneous deterioration in labor market indicators that measure long-term unemployment and layoffs. Benefit Exhaustions, which reflects long-term unemployment, ended its four-month string of improvement, rising by 4.1 percent in November. Along with this was an increase in New Claims for Unemployment Insurance, which measures layoffs, by 3.2 percent. This measure of layoffs remains in a rising trend.

New Claims is a leading indicator. It recent uptrend (note: it is desirable for layoffs, in terms of New Claims, to fall, not rise) bodes badly for our labor market in the coming months. But there is another leading labor market indicator included in the $\mathrm{CCl}$ : Employment Service Jobs, a labor category that includes "temps." This indicator rose by 5.4 percent in November, its most rapid rate of growth in over a year. Once again, offset in this month's economic performance.

Consistent with Rhode Island's highly sub-par employment performance (we ranked \#48 in November), sluggish growth in Private Service-Producing Employment continued in November, rising by only 0.6 percent. And Government Employment declined by 0.9 percent.

November was one of the rare months where both manufacturing sector indicators improved. Total Manufacturing Hours rose by 0.4 percent, its first increase since December of 2000. The Manufacturing Wage increased by 1.3 percent in November, its eleventh consecutive increase, but a weaker rate of growth than recent months. As I have noted in the last few reports, the recent performance of the Manufacturing Wage suggests the presence of labor shortages that have accelerated wage growth.

Finally, Labor Force growth remained well below its rates throughout much of this year, rising by 0.7 percent in November, while our Unemployment Rate increased slightly from 5.1 percent last November to 5.2 percent this November.

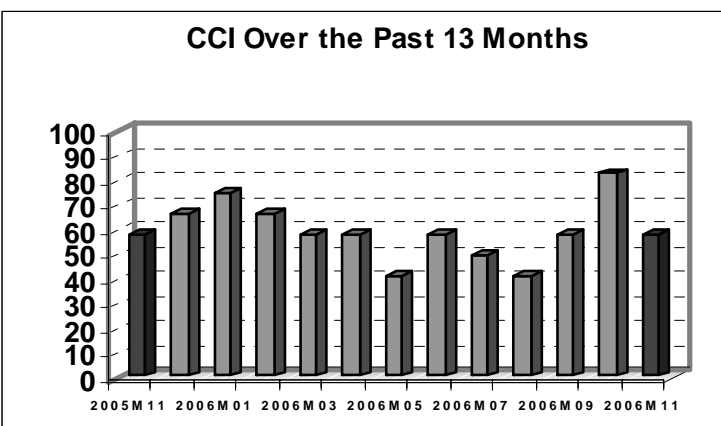

\section{THE BOTTOM LINE}

November's performance, while not spectacular, indicates that Rhode Island has returned to a pace of activity that is consistent with "first gear." Don't fret: this is a significant improvement over the marked weakness we experienced during May through August of this year.

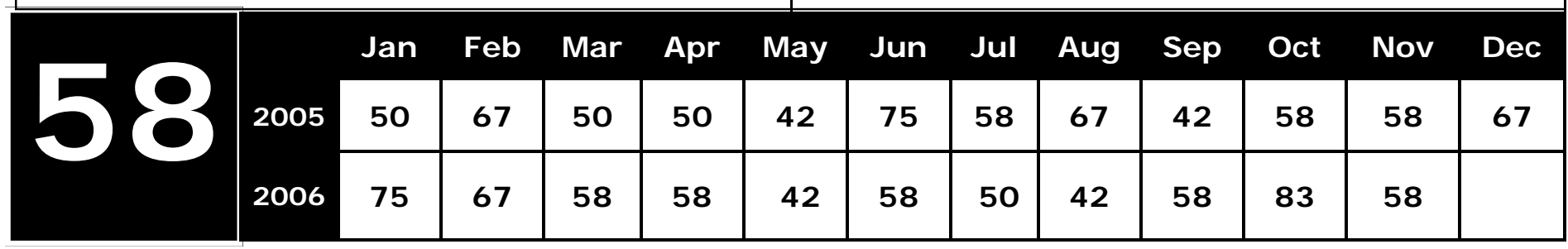

